\title{
Hermeneutiese uitdagings aan Christosentriese prediking vanuit Ou-Testamentiese narratiewe
}

\author{
Authors: \\ Hendrik S.W. Strauss ${ }^{1}$ \\ Friedrich W. de Wet ${ }^{1}$ \\ Affiliations: \\ ${ }^{1}$ Faculty of Theology, \\ North-West University, \\ Potchefstroom Campus, \\ South Africa \\ Correspondence to: \\ Hendrik Strauss \\ Email: \\ schalk.strauss@apk.co.za \\ Postal address: \\ PO Box 34542, Faunasig \\ 9325, South Africa \\ Dates: \\ Received: 23 Aug. 2013 \\ Accepted: 24 Apr. 2014 \\ Published: 17 Sept. 2014 \\ How to cite this article: \\ Strauss, H.S.W. \& De Wet, \\ F.W., 2014, 'Hermeneutiese \\ uitdagings aan \\ Christosentriese prediking \\ vanuit Ou-Testamentiese \\ narratiewe', In die Skriflig \\ 48(2), Art. \#1717, 11 pages. \\ http://dx.doi.org/10.4102/ \\ ids.v48i2.1717

\section{Copyright:} \\ (C) 2014. The Authors. \\ Licensee: AOSIS \\ OpenJournals. This work \\ is licensed under the \\ Creative Commons \\ Attribution License.
}

Read online:
Baie predikers vind dit moeilik om Christus vanuit die Ou Testament te verkondig. Die probleem van Christosentriese prediking uit die Ou Testament is wesenlik 'n hermeneutiese probleem. In hierdie artikel word gepoog om ' $n$ antwoord hierop te bied deur eerstens bepaalde ankers in 'n see van hermeneutiese moontlikhede te identifiseer. Hierdie ankers sluit in die Christelike karakter van die Ou Testament en die eenheid tussen die Ou en Nuwe Testament met ' $n$ universele boodskap. Ten einde Christus op 'n geloofwaardige en verantwoordelike wyse vanuit die $\mathrm{Ou}$ Testament te preek, is 'n eksegetiese metode waarin rekening gehou word met die karakter van die Ou Testament, sowel as die verhouding daarvan tot die Nuwe Testament, onontbeerlik. Die holisties histories-kritiese metode dien, na ons mening, Christosentriese prediking uit die Ou Testament die beste, aangesien dit die literêre, historiese en teologiese aspekte van 'n teks verreken. Terwyl 'n verantwoordelike eksegetiese metode die basis lê vir Christosentriese prediking uit die Ou Testament, word daar ook 'n verkenning gedoen van sinvolle (organiese) oorgange vanuit Ou-Testamentiese narratiewe na die Nuwe Testament. Aangesien Christosentriese prediking uit die Ou Testament nie sonder gevare is nie, word enkele slaggate ten opsigte daarvan uit die Ou-Testamentiese narratiewe uitgelig.

Hermeneutical challenges encountered by Christ-centered preaching from Old Testament narratives. Many ministers find it difficult to preach Christ from the Old Testament. The problem of Christocentric preaching from the Old Testament is essentially a hermeneutical problem. In this article an answer is proposed, firstly by identifying specific anchors in a sea of hermeneutic possibilities. These include the Christian character of the Old Testament, and the unity between the Old and New Testaments with a universal message. In order to preach Christ in a credible and responsible manner from the Old Testament, an exegetical method, which takes into account the character of the Old Testament as well as its relationship to the New Testament, is essential. The holistic historic-critical method, we believe, serves Christocentric preaching from the Old Testament the best as it takes the literary, historical and theological aspects of the text into consideration. As a responsible exegetical method lays the foundations for Christocentric preaching from the Old Testament, an exploration of meaningful (organic) transitions from Old Testament narratives to the New Testament is made. Seeing that Christocentric preaching from the Old Testament is not without dangers, some pitfalls regarding Christocentric preaching from the Old Testament narratives are highlighted.

\section{Inleiding}

In sy werk Preaching Christ from the Old Testament toon Greidanus (1999:1-2) hoe belangrik Christosentriese prediking nog altyd vir die Kerk was. Tog is een van die redes waarom Christus nie altyd vanuit die Ou Testament gepreek word nie, die feit dat baie predikers dit moeilik vind om die boodskap oor Jesus Christus daaruit te verkondig. Christosentriese prediking vanuit die $\mathrm{Ou}$ Testament is geen eenvoudige saak nie. Dit is duidelik uit die vele diskussies en debatte rondom die saak. Vergelyk byvoorbeeld Van Rooy (2001:82) se mening daaromtrent: "n Mens se siening oor die wyse waarop Christus in die Ou Testament voorkom, is fundamenteel belangrik vir die wyse waarop Christus uit die Ou Testament gepreek word.'

Só gesien, is die probleem rondom Christosentriese prediking vanuit die Ou Testament fundamenteel 'n hermeneutiese probleem. Daar sal dus in hierdie artikel gepoog word om 'n bydrae te lewer tot verantwoordelike Christusprediking vanuit Ou-Testamentiese narratiewe volgens 'n reformatoriese verstaan van die besondere karakter van die Ou Testament en die verhouding daarvan tot die Nuwe Testament. Hierdie artikel word opgedra aan die OuTestamentikus, Herrie van Rooy, wat deur sy navorsing 'n besondere bydrae tot die verstaan van hierdie probleemveld gelewer het. 
Die volgende gedagtelyn word gevolg in die ontplooiing van die artikel:

- Ankers in 'n see van hermeneutiese moontlikhede.

- 'n Verantwoordelike eksegetiese metode waarin rekening gehou word met die karakter van die Ou Testament sowel as die verhouding daarvan tot die Nuwe Testament.

- 'n Verkenning van sinvolle (organiese) oorgange vanuit Ou-Testamentiese narratiewe na die Nuwe Testament in Christosentriese prediking.

- Enkele voorbeelde hoe slaggate vermy kan word in Christosentriese prediking vanuit Ou-Testamentiese narratiewe.

\section{Ankers in 'n see van hermeneutiese moontlikhede}

Gereformeerde hermeneutiek verkeer tans in 'n impasse as gevolg van die invloed van postmodernisme (Jordaan, Janse van Rensburg \& Breed 2011:227; vgl. ook Goldsworthy 2006:135-137). Daar is geen plek vir die waarheid van 'n kontroleerbare bevinding nie; inteendeel, dit moet eerder plek maak vir die individu se subjektiewe persepsie van die waarheid en die werklikheid (vgl. De Wet 2011:4). 'n Deeglike verantwoording van die grondbeginsels wat gehandhaaf behoort te word tydens die hermeneutiese proses, is dus belangrik.

\section{Die unieke karakter van die Ou Testament}

Verklaarders se siening oor die Ou Testament is hermeneuties só bepalend dat dit alle interpretasies van die Ou Testament beheers (Greidanus 1999:39). Greidanus (1999:39-46) noem veral vier moontlike posisies wat ingeneem kan word jeens die Ou Testament:

1. Die Ou Testament is sub-Christelik.

2. Die Ou Testament is nie-Christelik.

3. Die Ou Testament is pre-Christelik.

4. Die Ou Testament is Christelik.

Laasgenoemde punt (Die Ou Testament is Christelik) behoort as anker te dien in die hermeneutiese proses, aangesien die $\mathrm{Ou}$ Testament wesenlik Christelik van aard is (Tipton 2011:213; vgl. ook Goldsworthy 2000:2). Die twyfel oor hoe daar uit 'n nie-Christelike of pre-Christelike boek 'n boodskap vir die Christelike kerk geformuleer behoort te word, is ' $n$ hermeneutiese vraagstuk wat deur die hedendaagse mens self aangevoer word. Om 'n boodskap vanuit die Ou Testament vir die Christelike kerk te formuleer, was nie problematies vir Nuwe-Testamentiese skrywers nie. Die ontvouing in die heilsgeskiedenis en openbaring vind plaas sonder om die verlede te diskwalifiseer. Ook Christus sien die inhoud van die Ou Testament as integrale deel van die een heilsgeskiedenis waarmee die ganse Skrif besig is (vgl. Matt 5:17; France 1985:114; Davies \& Allison 1988:484-487; Gundry 1994:80-81).

Robbertze (n.d.; vgl. ook Janse van Rensburg 2007:108-110) sluit sterk by laasgenoemde siening aan:
Die Nuwe Testament was dus nooit gesien as die geskrif van 'n nuwe religie nie, maar is gesien as die getuienis van 'n nuwe eskatologiese daad van dieselfde God wat altyd aan die werk was deur die wet en die profete en die geskrifte. (bl. 11)

Greidanus (1999:46-52) verduidelik die eenheid en interafhanklikheid van die Ou en Nuwe Testament aan die hand van die volgende vyf aspekte:

- Die Ou sowel as die Nuwe Testament is eskatologies van aard (verwag vervulling of afsluiting).

- 'n Enkele heilsgeskiedenis is onderliggend aan die Ou en Nuwe Testament.

- Jesus Christus vorm die skakel tussen die Ou en Nuwe Testament.

- Nuwe-Testamentiese skrywers se geskrifte is deurdrenk van die Ou Testament.

- Die Ou Testament moet vanuit 'n Nuwe-Testamentiese perspektief geïnterpreteer word.

Die Christelike hermeneut kan dus nie anders as om te aanvaar dat die Ou Testament Christelik van aard is nie. Die Ou Testament behoort dus vertolk te word binne die groter verhaal van die Bybel (vgl. Trimp 1988:29; Buttrick 1988:70-73), naamlik God se verlossingsverhaal of metanarratief (Goldsworthy 2002:282; 2006:201; Webber 2002:84-87; vgl. ook Bos 2008:ligging 889).

\section{Die eenheid tussen die Ou en Nuwe Testament en die een boodskap wat daarin verkondig word}

Goldsworthy (2000:xii-xiii; 2006:235; vgl. ook Strydom 1989) wys op die skeiding wat daar in die akademiese wêreld tussen die Ou en Nuwe Testament gekom het. Die vroeë kerkvaders het die eenheid tussen die Ou en Nuwe Testament gehandhaaf (Odendaal 2006:82-96).

Gaffin (vgl. Vos 1980:xvii-xviii) betoog dat die beginsel van sola scriptura op sigself hermeneuties toonaangewend is. Vanuit hierdie beginsel en die beginsel van sacra scriptura sui ipsius interpres, maak Gaffin die volgende afleiding: ' ... to say that Scripture interprets itself means that it has one pervasive sense - a unified meaning' (vgl. Vos 1980:xviii). Die Bybel is dus nie 'n aantal losstaande literêre eenhede of stories wat geen verband met mekaar het nie. Al hierdie onderdele is egter onlosmaaklik deel van 'n groter geheel. In hierdie groter geheel, die openbaringsgeskiedenis, neem Jesus Christus die sentrale plek in (De Wet 2007:459).

VanGemeren (1995:23) stel dit soos volg: 'The Old Testament and the New Testament are two forms of one divine administration of grace... The covenants and both Testaments are most significantly based on the one foundation; Christ ...' (outeurs se beklemtoning). Dit is Christus wat tussen die Ou en Nuwe Testament staan, wat dit skei en aan mekaar verbind (Jordaan et al. 2011:241). Alle spanningslyne kom in Christus bymekaar wat inhou dat daar nie 'n ander waarheid in die Nuwe Testament as in die Ou Testament geopenbaar word nie. 
Wanneer bogenoemde eenheid gehandhaaf word, behoort die feit dat die Woord slegs een boodskap ${ }^{1}$ bevat, naamlik God se verlossingsboodskap aan die mens soos vergestalt in Jesus Christus, ook erken te word (vgl. Goldsworthy 2000:16-18; Broadhurst 2006). Chapell (2005) verduidelik dit soos volg:

Christ's redemptive power and the power of his Word coalesce in the New Testament, with Logos (the incarnation of God) and logos (the message about God) becoming so reflexive as to form a conceptual identity. (p. 28)

De Wet (2011:27) noem Christus die 'saamtrekpunt en ontknopingspunt van dieSkrifopenbaring'. Wanneer Christus na sy opstanding uit die dood saam met die Emmaüsgangers stap, begin Hy vir hulle ál die Skrifte, vanaf Moses en die profete, uitlê en te verduidelik hoe die Ou-Testamentiese geskrifte op Hom betrekking het (Luk 24:27). Chapell (2005:279) verduidelik hoe hierdie uitspraak van Christus visueel uitgebeeld is tydens Christus se verheerliking op die Olyfberg.

Die apostels het vanuit die geloofsoortuiging dat die Here Jesus die vervulling van die wet en profete is, teruggekyk na die $\mathrm{Ou}$ Testament en dit in die lig van hulle kennis van Jesus Christus, die gekruisigde en opgestane Here, gelees en vertolk (Clowney 1986:165-166; vgl. Peels 2009:242). Om hierdie rede skryf Paulus ook in Romeine 1:1-4 (vgl. ook 1 Kor 15:1-4) van die evangelie van God 'wat Hy tevore beloof het deur sy profete in die heilige Skrifte'. Dit is die evangelie van Jesus Christus (vgl. Ciampa \& Rosner 2007:744; Tipton 2011:189-193). Die evangelie wat deur Christus en Paulus verkondig word, is dus in die geskrifte van die $\mathrm{Ou}$ Testament ingebed (vgl. Keller 2002:30; Baars 2007:244; Tipton 2011:186-187). In hierdie verband merk Tipton (2011:186) tereg op: '... the Old Testament, on its own terms, objectively foresignifies and supernaturally presents Christ to the faith of the Old Testament saints ...'. Volgens hom (Tipton 2011:200; vgl. ook Clowney 1986:163) is die Ou Testament nie van die Nuwe Testament afhanklik vir die openbaring van die evangelie nie, omdat die evangelie reeds daarin teenwoordig is.

Clowney (2003:39) meen dat die wyse waarop die Here Jesus self die Ou Testament hanteer het, die sleutel vir ons hantering daarvan is. Hoewel God van menslike outeurs gebruik gemaak het vir die opskrifstelling van sy geopenbaarde Woord, kan die boodskap en bedoeling van 'n teks nie apart van die bedoeling van die Goddelike outeur beskou word nie (vgl. Deist 1978:13; Broadhurst 2006). Tipton (2011:203-206) is van mening dat ons reeds in die historiese konteks van 'n teks nie slegs met die oorspronklike lesers se verstaan daarvan te doen het nie. Aangesien die $\mathrm{Ou}$ Testament ook God se besondere heilsopenbaring bevat, het ons dus ten diepste met God se bedoeling, soos uiteindelik beliggaam in Christus, te doen. Dit mag wees dat skrywers van die Ou Testament miskien self nie eens bewus was van die volle betekenis van dít wat hulle neergeskryf het nie.
Hulle onkunde oor die dieper en ryker betekenis van 'n teks impliseer egter nie dat God nie méér bedoel het as wat hulle gedink het nie (vgl. Greidanus, 1999:233; Phillips, Janse van Rensburg \& Van Rooy 2012:7).

Kaiser (2008) trek hewig te velde teen die standpunt dat God méér bedoel het as wat die oorspronklike skrywer bedoel het. Hy (Kaiser 2008) vra die vraag, 'But if the meaning God intended exceeds the meaning the human authors recorded, where shall we locate this additional surplus meaning?' Volgens Kaiser (2008) behoort die verklaarder na die historiese betekenis te soek en dan te kyk hoe God hierdie boodskap laat ontwikkel het tot in die Nuwe Testament. Dit bly egter 'n raaisel in hoe 'n mate God sy 'volle raad' aan die skrywers van die Ou Testament openbaar het (vgl. Job 15:8). Kon Hy nie ook kies om aan die skrywers deur middel van die openbaring 'n vergesig te gee waarvan die detail vir hulle nog nie so duidelik was nie? Heyns (1972:1-19; vgl. Burge 2009) is van mening dat die inspirasie ten opsigte van bepaalde sake moontlik selfs die skrywers se 'begrip en insig te bowe gegaan het'. Kaiser (1981:245) moet self gedeeltelik 'n toegewing maak in sy argument wanneer hy skryf: '... the search for the "übergeschichtliche" (superhistorical) moment is necessary if we are to discover the profound sense and lasting major value'.

\section{'n Verantwoordelike eksegetiese metode: Christosentries, met inbegrepe die karakter van die Ou Testament en die verhouding daarvan met die Nuwe Testament Inleidend}

Greidanus (1988:36-37) se holistiese histories-kritiese metode is ' $n$ aanpassing van die bestaande histories-kritiese metode, maar dit word deur ' $n$ bybelse wêreldbeskouing oorheers. Dit toon heelwat ooreenkomste met Kaiser (1981:69-165; Kaiser \& Silva 1994:33) se Sintakties-Teologiese Metode en Verhoef (1973:28) se voorstel vir 'filologiese eksegese'.

Greidanus (1988) beweer dat:

A holistic hermeneutical method seeks to take into account all aspects that contribute to the meaning of biblical texts and attempts to understand these aspects in the light of the whole and vice versa. (p. 49)

Soos die bekende histories-kritiese metode, neem die holistiese histories-kritiese metode ook aspekte soos literêre interpretasie in ag. Dit sluit in bron-, vorm-, redaksieen retoriese kritiek, in die lig van 'n bybelse teologie en interpretasie van historiese aspekte (vgl. Cilliers 2008:72), maar voeg ook 'n teologiese (dogmatiese) interpretasie van 'n teksgedeelte by. Hierdie metode laat die klem op die teks binne sy bybelse konteks val (Greidanus 1988:48). Kaiser (1981:69) merk tereg op dat goeie eksegetiese praktyk vereis dat die detail in die lig van die geheel beskou behoort te word. Die holistiese histories-kritiese metode help om die Ou Testament op 'n geldiger wyse te interpreteer, aangesien 
hierdie metode die hermeneut toelaat om veral die historiese narratiewe in die Skrif te herken en te interpreteer vir wat hulle is, en nie slegs as ' $n$ mite, legende, gelykenis of blote 'stories' nie (Greidanus 1988:47).

\section{Kenmerkende elemente in die holistiese histories-kritiese metode}

\section{Klem op die grammatiese element van die teks}

Die verklaring van 'n teks is op eksegese van die grondteks gebaseer (Hoekstra 1926:281). Krabbendam (1986:217) som dit op wanneer hy sê dat die betekenis van 'n teks ontdek, herken en geverifieer kan word deur middel van grammatikale, sintaktiese en semantiese studie daarvan. ${ }^{2}$ Hierdie grammatikale studie behoort die hermeneutiese beginsels, wat vervolgens bespreek word, ten grondslag te lê.

\section{Gedagte-eenheid van 'n afgebakende teksgedeelte}

Dit is belangrik dat die gekose teksgedeelte 'n gedagte of literêre eenheid vorm. Chapell (2005:60-61) noem dit 'n 'expository unit'. Hoewel so 'n literêre eenheid soms so kort as slegs een sin kan wees, bestaan dit, in die geval van narratiewe gedeeltes, gewoonlik uit een of meer paragrawe (Verhoef 1973:34; Craddock 1985:110-112; Long 1989:64).

\section{Interpretasie binne die totale konteks}

Die Hebreeuse narratief is ' $n$ spesifieke literatuursoort ${ }^{3}$ en vereis dus ook 'n spesifieke hermeneutiese aanslag. Aandag aan detail is noodsaaklik en die regte vrae behoort aan die teks gevra te word (Strauss 2012:58-59). Dit gebeur baie maklik dat narratiewe van die literêre konteks waarin hulle staan, geïsoleer word. Dit is belangrik dat die betekenis van 'n spesifieke narratief alleenlik bepaal en verkondig behoort te word binne die konteks ${ }^{4}$ van die hele boek en uiteindelik binne die Bybel as 'n geheel, aangesien elke onderdeel se spesifieke betekenis eers binne die konteks van die groter geheel duidelik word (Greidanus 1988:213; Kaiser 1981:69-70; vgl. ook Clements 1978:27-32 en Krabbendam 1986:217).

\section{Hoor die teks soos die oorspronklike hoorder}

God se opskrifgestelde woorde en dade het, in die meeste gevalle, 'n konkreet-historiese konteks (vgl. Verhoef 1973:61). Die doel van die historiese verstaan van 'n teksgedeelte is om die betekenis daarvan binne sy eie historiese en kulturele konteks te bepaal (vgl. Bright 1967:169). Dingemans (1991:109) is van mening dat, wanneer 'n mens die historiese basis miskyk, tekste die geneigdheid het om te vervaag tot algemene waarhede wat ook buite die gebeure om bedink kan word. Ten einde die narratief behoorlik te interpreteer, is die historiese vrae met betrekking tot die outeur, die eerste hoorders, die tyd, die sosiale en geografiese plasing en die

2.Vir ' $n$ vollediger bespreking van grammatikale eksegese, vergelyk Verhoef 1973:28-35; Kaiser 1981:87-129 en Greidanus 1988:48-67.

3.Vir ' $n$ bespreking van die Hebreeuse narratief, vergelyk Strauss 2012:10-29.

4.Vir ' $n$ vollediger bespreking van die verskillende kontekste wat tydens literêre interpretasie in ag geneem behoort te word, vergelyk Strauss 2012:56-58. doel (waarom?) van die skrywe baie belangrik, aangesien dit sekere leidrade bevat wat help met die vasstelling van die doel van 'n bepaalde gedeelte (Greidanus 1999:229; Chapell 2005:108; vgl. ook Kaiser 1981:106-121; Keller 2002:26).

Daar bestaan besware teen die gebruik van die grammatieshistoriese benadering, aangesien dit blyk dat die sogenaamde 'eerste lees' van die Ou-Testamentiese teks, waarvolgens die eerste hoorders se 'verstaan' daarvan vasgestel word, nie Christosentries of evangelies gerig kan wees nie (vgl. Tipton 2011:201 e.v.). Tog toon Tipton (2011:186-213) op 'n omvattende wyse aan dat die evangelie, hoewel soms in wording, wel in die oorspronklike bedoeling van die teks teenwoordig is.

\section{Die teks in die lig van koninkryksgeskiedenis}

Hoewel daar verskeie voorstelle vir 'n allesoorkoepelende tema vir die Bybel is (Greidanus 1988:69-70; vgl. ook Strydom 1989 en Krabbendam 1986:220-221 se gebruik van die tema, 'Verbond'), blyk die tema, 'koninkryk van God' (vgl. ook Ridderbos 1950; Van der Walt 1962), die sinvolste te wees. Dit is die mees omvattende en inklusiewe van al die voorgestelde temas. Historiese interpretasie besit die vermoë om die kontinuïteit tussen toe en nou te beklemtoon deurdat dit geskiedkundige verwysings en historiese narratiewe verstaan binne die konteks van die universele koninkryksgeskiedenis wat van die skepping tot die herskepping strek. Een manier om reg te laat geskied aan die groter raamwerk, is om elke narratief binne die konteks van die oorkoepelende tema van bybelse geskiedskrywing te beskou.

\section{Teologiese onderbou van 'n Skrifgedeelte met inagneming van die Christosentriese fokus}

Die historiese narratief in die Ou Testament het 'n spesifieke teologiese doel sodat ' $n$ beeld van God gevorm kan word (Clements 1978:34; vgl. Strydom 1989:143). Dit is juis hierdie teologiese interpretasie wat die 'onafheid', dit wil sê die openheid van 'n teks vir verdere interpretasie, in die kontekstuele boodskap uitlig en die potensiaal bied om na Christus te beweeg (Robbertze 2003:151). Tydens die teologiese interpretasie van ' $\mathrm{n}$ teks behoort gevra te word: Wat openbaar God oor Homself en sy wil in hierdie teksgedeelte? (Hoekstra 1926:292; Schilder 1983:17; Greidanus 1988:216). Die hermeneut behoort noukeurig daarop te let dat hy nie op 'n subjektiewe wyse 'van buite', 'n bepaalde teologie op die teks afdwing nie, maar eerder vanuit die teks self tot teologiese gevolgtrekkings kom (Kaiser 1981:134-138).

Sonder teologiese interpretasie is dit maklik om in die slaggat van antroposentriese prediking te trap, aangesien dit kan voorkom asof die menslike karakters in bybelse narratiewe voorop staan (Greidanus 1970:140; 1988:216; vgl. ook Krabbendam 1986:231-232). Die hermeneut moet nie vergeet dat die Bybel nie daar is om aan ons interessante wetenswaardighede in verband met die doen en late van mense en volke in 'n bepaalde tydvak van die geskiedenis 
mee te deel nie. Die Bybel is daar om ons in te lig oor wie God is en wat Hy gedoen het om sy heil aan ons te openbaar (Verhoef 1973:72).

Hebreeuse narratiewe het 'n duidelik-waarneembare teosentriese fokus (Davies 2006:4). Dit word duidelik uit die feit dat God dikwels een van die 'karakters' in 'n toneel is, maar ook uit die feit dat die verteller dikwels die verhaal vanuit 'God se oogpunt' vertel. Selfs waar God oënskynlik afwesig blyk te wees, is dit opmerklik hoe die geheelbeeld God se teenwoordigheid onthul, aangesien die karakters optree teen die agtergrond van God se beloftes, sy krag wat as motivering dien en sy voorsienigheid (Greidanus 1988:217). Fee en Stuart (2003:79) beskryf die teosentriese doelwit van historiese narratiewe in die Bybel soos volg: 'Their purpose is to show God at work ... The narratives glorify Him, help us to understand and appreciate Him, and give us a picture of His providence and protection.'

Hierdie teologiese onderbou bring uiteindelik die Christosentriese fokus na vore. Christelike prediking is altyd Christelik van aard (Buttrick 1987:14, 233-234). Wanneer teosentriese interpretasie van 'n teks eerlik gedoen word, sal Christus nie in 'n teks ingeforseer word nie. Die rede daarvoor is dat teosentriese interpretasie, vanuit ' $n$ NuweTestamentiese perspektief beskou, reeds Christosentries is, omdat Christus die ewige Logos is (Greidanus 1988:220; Vos 1995:388). Dit beteken egter nie dat 'n Christosentriese interpretasie onmoontlik is sonder die lig wat die Nuwe Testament op 'n Ou-Testamentiese teks of geloofsaspek werp nie. Tipton (2011:206) waarsku juis dat wanneer geredeneer word dat tipologie uitsluitlik uit die vervulling in Christus voortvloei, dit die oorspronklike heilsopenbaring van God in die $\mathrm{Ou}$ Testament stroop van enige inherente tipologiese betekenis.

Vos (1995:388, 391; vgl. Davis 2006:134-138) waarsku teen gedwonge Christologiese interpretasie van die Ou Testament en pleit eerder vir Christosentriese interpretasie wat uit 'n teosentriese interpretasievan die teks voortvloei. Krabbendam (1986:227) se waarskuwing dat Christosentriese interpretasie die fokus van die bybelse boodskap kan vernou, behoort nie ligtelik opgeneem te word nie. Hoewel Krabbendam en Davis die gebruik van Christosentriese interpretasie afraai, is dit moontlik dat wanneer Christosentriese interpretasie verantwoordelik toegepas word, dit juis níe die boodskap van die Ou Testament vernou nie, maar eerder verbreed (vgl. Greidanus 1999:227).

'n Christosentriese interpretasie van ' $n$ teks gaan oor meer as om net sporadiese tipes, anti-tipes, skadubeelde of vervulde Messiaanse profesieë na te speur (vgl. Chapell 2001). Volgens Schilder (vgl. Greidanus 1970:143; Robbertze 2003:149) se siening kan 'n prediker nie ware Christosentriese preke lewer, indien hy bloot hier en daar klein Messiaanse 'liggies' in die $\mathrm{Ou}$ Testament ontdek nie, maar intussen misluk hy om die ontplooiing van die Messiaanse selfopenbaring en selfvoorbereiding van die Logos raak te sien. Dit gaan daaroor dat 'n teks binne die groter konteks van die universele koninkryksgeskiedenis waarvan Christus die doel en klimaks is, verstaan behoort te word (Bright 1967:210).

\section{Sinvolle (organiese) oorgange vanuit Ou-Testamentiese narratiewe na die Nuwe Testament}

\section{Fokus op die mens se in-sonde-gevalle toestand (Fallen condition focus - FCF)}

Die FCF werk met die volgende vrae: Watter menslike tekortkoming het die Heilige Gees genoodsaak om 'n spesifieke Skrifgedeelte te inspireer? (Greidanus 1988:110-111; 1999:229; Chapell 2001; 2005:48; vgl. ook Jordaan et al. 2011:253); en Watter aspek van die mens in sy onvolmaaktheid, word deur 'n spesifieke teks aangeraak ten einde dit tot volmaaktheid te bring? (vgl. 2 Tim 3:16-17).

Die mens se gebrek aan volmaaktheid is ' $n$ gevolg van die gevalle toestand waarin hy leef (Chapell 2005:49). Robinson (1997:24) verduidelik dat elke teks 'n spesifieke beeld van God bevat. Daarom is dit belangrik om te vra: 'What is the depravity factor? What in humanity rebels against that vision of God?' God gebruik die waarhede van die Skrif om die mens in sy sondenood te hulp te kom deur sy genade in elke aspek van die mens se gevallenheid te openbaar. Chapell (2005) gee die volgende definisie van die FCF:

Fallen Condition Focus is the mutual human condition that contemporary believers share with those to or about whom the text was written that requires the grace of the passage for God's people to glorify and enjoy him. (p. 50)

Daar kan dus nie met Buttrick (1987:269) saamgestem word dat daar geen konstante te bespeur is in die menslike natuur wat kan help om die gaping tussen tóé en nóú te oorbrug nie. Hoewel daar waardering is vir, wat hy noem, die misbruike in die soeke na so 'n konstante, ignoreer hy die een tydlose konstante in die menslike natuur, naamlik sy in-sonde-gevalletoestand.

Die vasstel van die FCF is van groot waarde vir die Christosentriese prediking van 'n Skrifgedeelte (vgl. Keller 2011). Wanneer die FCF duidelik geartikuleer word, beheer dit die toepassing van 'n teksgedeelte en sorg dat dit Christosentries bly, aangesien Christus alleen die Verlosser vir die in-sonde-gevalle mens is (Chapell 2005:54). Goldsworthy (2000:62) waarsku dat, wanneer die FCF nie deur die evangelie herdefinieer word nie, loop die prediker gevaar om in 'n pragmatiese boodskap te verval. Keller (2002:43) maak 'n belangrike opmerking wanneer hy aantoon dat die heilshistoriese hantering van 'n teks sonder die FCF onvolledig is: 'It is theologically right to anchor every way of preaching Christ both in the history of redemption and in the incomplete condition of the listeners.'

Die FCF hoef nie noodwendig 'n spesifieke sonde te wees nie, maar kan ook een van die gevolge van die sondeval wees, byvoorbeeld siekte, dood, hartseer, verlange, die behoefte 
om te weet hoe om die Evangelie te verkondig, ensovoorts (Chapell 2005:51). 'n FCF van 'n teksgedeelte word altyd negatief geformuleer, aangesien dit 'n sonde of 'n gevolg van die sondeval hanteer wat herstel of bemoediging uit die Skrif benodig.

Chapell (2005:52; vgl. ook Kaiser 1981:153-156; Craddock 1985:136-150) doen die volgende vrae aan die hand ten einde die FCF van 'n teksgedeelte vas te stel:

1. Wat sê die teks?

2. Watter geestelike nood/behoefte(s) word deur die teks binne konteks hanteer?

3. Watter geestelike nood/behoefte(s) het hoorders in gemeen met hulle aan wie of oor wie die teks geskryf is?

Tussen vraag 2 en 3 kan 'n vierde vraag ingevoeg word wat ook deur Chapell (2005:80) voorgestel word, naamlik Hoe verwoord hierdie teks die bedoeling van of die behoefte aan verlossing?

\section{Aspekte van verbindingslyne na Christus met enkele voorbeelde uit die aartsvader narratiewe}

\section{Heilshistoriese ontplooiing ${ }^{5}$}

Heilshistoriese ontplooiing lê die grondslag vir die ander ses voorgestelde maniere waarop Christus vanuit die $\mathrm{Ou}$ Testament gepreek kan word (vgl. Clowney 1986:174; Greidanus 1999:234; 2008; Peels 2009:249). Deur 'n teks binne die konteks van die verlossingsgeskiedenis te plaas, word intertekstuele verbande raakgesien (Goldsworthy 2000:99).

Greidanus (2007) maak die volgende opmerking:

When a text witnesses to God's saving activity in history, we find ourselves on a road that progresses steadily through the Old Testament, leads to God's ultimate saving act in the sending of his Son, Jesus Christ, and culminates in Jesus' Second Coming. (p. 3)

Volgens Goldsworthy $(2000: 51 ; 2006: 48)$ het Christus Homself as Een beskou wat binne die heilsgeskiedenis optree, maar wat ook die hele proses van heilsgeskiedenis tot 'n klimaks voer. Greidanus (1999:235) wys op vier spilpunte wat in die heilsgeskiedenis waargeneem kan word, te wete:

1. Skepping (chaos word verander in 'n gestruktureerde koninkryk).

2. Ou-Testamentiese verlossing (God verlos sy volk om lig vir die nasies te wees).

3. Verlossing deur Jesus Christus (verlossing vir alle mense en herstel van God se koninkryk).

4. Nuwe skepping (finale oorwinning oor die bose en volmaakte koninkryk op aarde).

Die heilsgeskiedenis is 'n beskrywing van God se verlossingsdade aan sy volk. Hy inisieer hierdie hele proses en wanneer dit herken word, dien dit as skakel wat help om Christus as die klimaks van God se magtige verlossingsdade te herken (Greidanus 1999:191-195, 236; vgl. ook Tipton 2011:186-189).

5. Kyk Strauss 2012:41-45 vir verdere bespreking van die heilshistoriese konteks.
Dit is verder belangrik dat die heilsgeskiedenis as ' $n$ geheel beskou word. Die Ou Testament behoort nie bloot as 'n soort 'proof text' (Greidanus 1999:194) in verband met Jesus Christus gebruik te word nie. Volgens Christus is die getuienis oor sy dood en opstanding nie slegs in sekere tekste van die $\mathrm{Ou}$ Testament te vinde nie, maar oral (vgl. Luk 24:44-47; Goldsworthy 2000:54; Tipton 2011:192). Von Rad (1980:155; vgl. ook Greidanus 1999:237; Tipton 2011:187) merk op dat 'Old Testament history, in judgment and in salvation, bears witness to that action of God that becomes finally revealed in Jesus Christ.'

Dit is belangrik om in ag te neem dat Ou-Testamentiese narratiewe op drie vlakke beskou kan word. Die eerste vlak is wanneer die verhaal as persoonlike geskiedenis beskou word (bv. Gen 17 as Abraham se verbintenis met God); die tweede vlak is wanneer dit as nasionale geskiedenis beskou word (bv. Gen 17 as Israel se verbintenis met God); en die derde vlak wanneer dit as heilsgeskiedenis beskou word (bv. Gen 17 as God se ooreenkoms met sy kinders; Greidanus 1999:238). Dit is belangrik om nie aartsvaderverhale slegs op die derde vlak te verklaar nie. Daar behoort deur al drie vlakke tot op die derde vlak beweeg te word. ${ }^{6}$

\section{Belofte-vervulling}

Clowney (1986:172-173; vgl. ookJansevan Rensburg 2007:117) is van mening dat die Ou Testament struktureel deur God se belofte gevorm is. Vir die tradisionele Christendom is dit nie moeilik om Jesus Christus met die beloofde Messias van Israel te verbind nie (Childs 1993:452). Hoewel 'n groot hoeveelheid Ou-Testamentici die oorsprong van Messiaanse hoop terugvoer na die ontstaan van die Dawidiese koningshuis en die gepaardgaande belofte van ewige koningskap (Childs 1993:453), is daar tog ook Ou-Testamentici wat God se belofte(s) wyer sien as slegs 'messiaanse hoop' en dit selfs terugspoor na Genesis 3:15 (Greidanus 1999:241; vgl. ook Clowney 1986:170). Goldsworthy (2000:48) dui aan hoedat Jesus Homself nie as Iemand beskou het wat die oue tot niet maak om iets heeltemal nuuts daar te stel nie, maar die evangeliese gebeure word beskou as die voltooiing en vervulling van God se verlossingsdade en beloftes in die Ou Testament.

Van Rooy (2001:95-96) lewer belangrike kritiek op Greidanus se hantering van belofte-vervulling, naamlik dat hy slegs op direkte Messiaanse beloftes konsentreer en nie noodwendig daardie beloftes hanteer wat nie Messiaans van aard is nie. Belofte-vervulling behoort dus wyer as net die spesifieke Messiaanse beloftes van die Ou Testament gesien te word, aangesien elke Ou-Testamentiese belofte (selfs wanneer 'n vervullingsmoment hiervan reeds in die Ou Testament beleef is) ten diepste in Christus vervul word as klimaks in die vervullingsproses. Daar behoort egter daarteen gewaak te word om alle tekste in hierdie model te forseer (vgl. Baars 2007:262).

6.Vergelyk Strauss (2012:177-178; 182-186) se gebruik van hierdie metode aan die hand 'n preekvoorbeeld uit Genesis 22:1-19. 
Volgens Greidanus (1999:242) is daar veral twee belangrike reëls wat in ag geneem behoort te word wanneer gepoog word om die Ou-Testamentiese beloftes te interpreteer:

1. God (ver)vul sy beloftes gewoonlik progressief (vgl. Greidanus 1999:242; Goldsworthy 2000:78-79).

2. Tydens interpretasie behoort daar van die OuTestamentiese belofte na Christus en weer terug na die teks beweeg te word sodat die volle impak van die belofte ontgin kan word (vgl. Baars 2007:262; Peels 2009:253).

Ten opsigte van die aartsvaderverhale toon Greidanus (2007:8-9) vier tekste aan wat as tradisionele Messiaanse tekste binne die aartsvaderverhale bekend staan en aan die hand van belofte-vervulling hanteer behoort te word, naamlik Genesis 12:3; 26:3; 46:3 en 49:10. Hierdie tekste kan egter nie in kontekstuele isolasie gelees word nie, aangesien dit in die konteks van Genesis 3:15 ingebed is (vgl. Greidanus 2007:12).

Keller (2002:38) wys ook daarop dat baie interkanonieke temas aan eksplisiete Ou-Testamentiese beloftes verbind is. Volgens Davies (2006:31-33) is God se belofte aan Abraham in Genesis 12 veral deurslaggewend vir die interpretasie van die aartsvaderverhale. Jesus Christus is die vervulling van hierdie beloftes en predikers behoort implisiet of eksplisiet daarnatoe te beweeg (vgl. ook Tipton 2011:196). Hierdie metode bring die volle skopus van die koninkryksgeskiedenis in die gesigsveld (Greidanus 1999:248).

\section{Tipologie}

Tipologie is die dominante wyse waarop die Nuwe Testament die Ou Testament hanteer (vgl. Glenny 1997:627). Keller (2002:35) waarsku egter dat tipologie nie die enigste wyse is om die Ou Testament Christosentries te verklaar nie, aangesien die meeste $\mathrm{Ou}$-Testamentiese tekste nie tipes van Christus bevat nie.

Die wese van tipologie is geleë in die erkenning dat in die Skrif self 'n besondere verhouding bestaan tussen sekere gebeure, mense en instellings in die bybelse geskiedenis en latere gebeure, mense en instellings (Glenny 1997:629; Goldsworthy 2000:77). Greidanus ${ }^{7}$ (1999) verduidelik die verskil tussen allegorie en tipologie soos volg:

Typology is quite different from allegorical interpretation, which can make a text say whatever the interpreter wants to make of it. Typology, by contrast, is limited to discovering specific analogies along the axis of God's acts in redemptive history as revealed in Scripture. (p. 249)

Bos (2008:ligging 445) voeg by dat tipologiese interpretasie, anders as allegorie, reg laat geskied aan die historiese en literêre betekenis van 'n teks. Tipologie erken dat die oorspronklike historiese betekenis van 'n teks teologies verbind kan word aan 'n latere uitdrukking wat dit volmaak of voltooi (Trimp 1988:50; Goldsworthy 2000:77).

Greidanus (1999:250-252) verduidelik dat Ou-Testamentiese tipes voorspellend sowel as nie-voorspellend van aard is. 7.Vergelyk Van Rooy (2001:96) se kritiek op Greidanus se hantering van tipologie.
Dit is heel waarskynlik dat Israel nie Dawid se koningskap aanvanklik as ' $n$ voorspelling van 'n groter koning gesien het nie, maar die wyse waarop die profete Dawid se koningskap hanteer het, het daarvan 'n tipe gemaak. Ander sake of persone in die $\mathrm{Ou}$ Testament is egter uit die staanspoor bedoel as tipes.

Die uniekheid van Ou-Testamentiese tipes is daarin geleë dat daar ooreenkomste sowel as verskille tussen tipe en antitipe bestaan (Clowney 1988:14). Greidanus (1999:254-255; Chapell 2005:281; Baars 2007:257) haal die volgende definisie vir 'tipes' in die Ou Testament van Eichrodt aan: 'Types are persons, institutions, and events of the Old Testament which are regarded as divinely established models or prerepresentations of corresponding realities in the New Testament salvation history.' Goldsworthy (2000:111) voeg die belangrike opmerking hier by dat ooreenkomste nie net tussen persone, gebeure en instellings te vinde is nie, maar dat selfs 'n hele epog van openbaring as tipe kan dien - die sogenaamde 'makrotipologie' (Goldsworthy 2006:250-257; 2012:184-189).

Greidanus (1999:256; vgl. ook Goldsworthy 2000:111; 2006:247; Baars 2007:259 en Bos 2008:ligging 559) identifiseer vier eienskappe waaraan tipes in die Ou Testament uitgeken word. Hierby kan ook 'n vyfde eienskap gevoeg word:

1. Slegs historiese feite (persone, aksies, gebeure en instellings) is materiaal vir tipes.

2. ' $\mathrm{n}$ Ware tipe is teosentries omdat dit te doen het met God se aksies in en deur mense.

3. 'n Ware tipe toon 'n duidelike ooreenkoms (histories en teologies) met 'n antitipe (vgl. ook Goldsworthy 2000:77, 111).

4. Die verhouding tussen die tipe en die antitipe word gekenmerk deur eskalasie (bv. 'meer as Jona is hier' of 'meer as Salomo is hier'; Matt 12:41-42; vgl. ook Fabiny 2009:138).

5. Tipes is eskatologies en Christologies van aard.

Greidanus (1999:257-258) stipuleer die volgende reëls vir die gebruik van tipologie:

1. Tipologiese interpretasie behoort altyd deur literêrhistoriese interpretasie voorafgegaan te word (vgl. Janse van Rensburg 2007:114).

2. Daar behoort nie vir tipes in teksdetail gesoek te word nie, maar in die sentrale boodskap daarvan (vgl. Keller 2002:31).

3. Soek na die simboliese betekenis van'n persoon, instelling of gebeurtens in die Ou-Testamentiese tyd (vgl. Clowney 1986:179-183; Keller 2002:30).

4. Let op die verskille tussen die Ou-Testamentiese tipe en die Nuwe-Testamentiese antitipe.

5. Wanneer daar van die Ou-Testamentiese tipe of simbool na Christus beweeg word, is dit belangrik om die oorspronklik betekenis van die simbool oor te dra.

6. Moenie slegs lyne vanuit die Ou Testament na Christus trek nie. Christus behoort gepreek te word. Dit beteken dat die lyn wat na Christus getrek word, relevant gemaak behoort te word. 
Hierby kan, in die lig van Greidanus (1999:260) se waarskuwing dat nie alle sake rondom die tipe op die antitipe van toepassing gemaak kan word nie, nog 'n sewende reël gevoeg word:

7. Geen Ou-Testamentiese tipe is 'n volledige, allesomvattende voorstelling van die antitipe, Jesus Christus, nie. Daarom wys Keller (2002:41-42) daarop dat daar nie noodwendig na 'n 'goeie voorbeeld' in 'n teks gesoek hoef te word om by Christus uit te kom nie. Christus kan soms aan die hand van kontrastering gepreek word.

Hierdie reëls is belangrik wanneer die aartsvaderverhale geïnterpreteer word, aangesien dit maklik gebeur dat onbenullige detail in ' $n$ teks as ' $n$ tipe voorgestel word (bv. die brandofferhout wat Isak dra as tipe van Christus se kruis).

\section{Analogie \\ Analogie is waarskynlik die mees gebruikte metode waardeur die Ou Testament met die hedendaagse Christelike lewe verbind word (vgl. Greidanus 1999:262). Wanneer Israel, of die aartsvaders, se situasie in hulle verhouding met God ooreenkom met wat tans beleef word, verkry die Woord eietydse relevansie (vgl. ook Krabbendam 1986:237-240 se bespreking van Universele Beginsels). Von Rad (1980:156) wys daarop dat die Kerk opnuut beweeg van belofte na vervulling en daarom is daar sprake van 'n parallelle situasie tussen die Kerk en die volk van die Ou Testament. Analogie is op die eenheid in heilsgeskiedenis en die gemeenskaplikheid tussen die Kerk en Israel gebaseer (vgl. ook Dijk 1955:109) wat alleen moontlik is in, maar ook afhanklik is van, Christus (Greidanus 1999:262).}

Ten einde die weg van analogie as oorgang vanuit die aartsvaderverhale na Christus te kies, behoort die historiese konteks en interpretasie van 'n teksgedeelte deeglik verreken te word. Die weg van analogie staan ook in nou verband met die FCF van 'n teksgedeelte, aangesien dit juis die gemeenskaplikheid tussen eerste hoorders en hedendaagse hoorders blootlê.

\section{Deurlopende temas}

Deurlopende temas is in elke historiese epog sigbaar (Keller 2002:21). Ook die aartsvaderverhale vind hulle oplossing in Christus (Keller 2002:36-39). Verhoef (1977:147-148) verwys hierna as verskillende bane op die snelweg tussen die Ou en Nuwe Testament. Hierbinne is God se kerugma opgesluit. Die temas van hierdie kerugma moet na die Nuwe Testament deurgetrek word ten einde die boodskap vir die eietydse kerk vas te stel (vgl. ook Janse van Rensburg 2007:122-123). Dit kan slegs gedoen word indien Christus die brug is (Verhoef 1977:149-151).

Greidanus (2007:17-21) noem ses verweefde temas wat die aartsvaderverhale tot ' $n$ eenheid bind:

1. Die koninkryk van God.

2. God se seën en vloek.

3. God se verbond.
4. Verbondsbeloftes.

5. Die belofte van 'n nageslag.

6. Die begin van die heilsgeskiedenis.

\section{Nuwe-Testamentiese verwysings}

Nuwe-Testamentiese skrywers se gebruik en toepassing van die Ou Testament in hulle geskrifte, kan waardevol vir Christosentriese prediking wees (Greidanus 1999:269; vgl. Beale \& Carson 2007:xxvi-xxviii), veral omdat dit dikwels deurlopende temas aantoon en ontbloot. Daarom is Janse van Rensburg (2007:123) van mening dat Achtemeier se paringsidee, waarvolgens ' $\mathrm{n} \mathrm{Ou}$ - en Nuwe-Testamentiese teks saam hanteer word, tog van waarde kan wees. Indien die prediker dus probleme ondervind om so 'n tema in die teks van die Ou Testament te identifiseer, kan die Nuwe Testament se gebruik van die teks hierin behulpsaam wees. Die beste wyse waarop Nuwe-Testamentiese verwysings gebruik kan word, is om as ondersteuning te dien vir een van die ander weë wat na Christus lei (Greidanus 2007:6).

\section{Kontras}

Weens die progressie in die geskiedenis van verlossing en openbaring, staan die boodskap van die Ou en Nuwe Testament soms in kontras met mekaar (Greidanus 1999:271; vgl. Baars 2007:264-266). Die weg van kontras sentreer duidelik in Christus, aangesien Hy alleen vir die verandering tussen die boodskappe van die $\mathrm{Ou}$ en Nuwe Testament verantwoordelik is (Greidanus 1999:272), byvoorbeeld God was by Josef in voor- en teëspoed, maar aan die kruis was Christus van God verlate (vgl. Greidanus 2007:386). Wanneer Christus die vervulling van elke teks in die Ou Testament is, vorm Hy nie slegs 'n ooreenkoms met elke teks nie, maar soms ook'n kontras (Keller 2002:41-42).

\section{Enkele voorbeelde van hoe slaggate vermy kan word in Christosentriese prediking vanuit Ou-Testamentiese narratiewe}

Wanneer die heilshistoriese konteks van die Ou Testament geïgnoreer word, is dit maklik om die mikrokonteks van 'n teks te oorbeklemtoon en slegs die betekenis van 'n teks in sy onmiddellike konteks te belig (vgl. Chapell 2005:275-276). Die teendeel is egter ook waar, naamlik dat die makrokonteks ten koste van die mikrokonteks oorbeklemtoon kan word (vgl. Keller 2002:26). Dit gebeur wanneer daar te vinnig vanaf die Ou-Testamentiese teks na Christus beweeg word (vgl. Keller 2002:16), byvoorbeeld wanneer die offerlam in Genesis 22:1-19 direk op Christus van toepassing gemaak word.

Slaggate kan ook vermy word wanneer daar nie in elke teks 'n spesifieke verwysing na Christus gesoek of 'ontdek' word nie (vgl. Davies 2006:134), maar eerder deur op 'n organiese wyse vanuit die boodskap van die teks na Christus te beweeg. Daarom waarsku VanGemeren (1984:281) ook ten opsigte van belofte-vervulling: 'The danger exists of reading the New 
Testament into the Old Testament and thereby missing aspects of hope and promise ... in the Old Testament passage ...'.

In 'n poging om nie slegs die oninteressante (heils)historiese feite weer te gee nie, trap baie predikers in die slaggat van allegorisering (Kaiser 1981:132). Keller (2002:30; vgl. ook Fee \& Stuart 2003:103) meen dat wanneer tipologie as oorgang gebruik word, allegorisering vermy kan word deur die oorspronklike bedoeling van die teks voortdurend in ag te neem; indien daar nie op allerhande onbenullige detail in 'n teks gefokus word nie (Greidanus 1999:252-253 noem dit tipologisering); indien die simboliek slegs gesoek word in dít wat vir die Ou-Testamentiese skrywer en hoorder simboliese waarde gehad het; en indien dit op makro-eienskappe en figure fokus. Die identifisering van toevallige ooreenkomste met Christus kan ook lei tot allegorisering (Greidanus 1999:253).

Indien die boodskap van 'n Ou-Testamentiese teks nie op geloofwaardige wyse geïntegreer word met die persoon, werk en lering van Jesus Christus nie, maar daar eerder op oppervlakkige wyse na ooreenkomste met Christus in die teks gesoek word, is allegorisering ' $n$ wesenlike gevaar (Keller 2002:28). Sodoende word die teks op gedwonge wyse Christologies hanteer (Vos 1995:379).

Wanneer die heilshistoriese benadering nie ook die teosentriese fokus van die Skrif in ag neem nie, maar uitsluitlik op Christus fokus, waarsku Greidanus (1999:178; vgl. ook Goldsworthy 2006:65) teen die gevaar van Christomonisme waarvolgens Christus in isolasie van God verkondig word. Wie egter getrou aan 'n evangelie-gesentreerde verklaring bly, behoort hierdie slaggat te kan vermy (Goldsworthy 2006:66).

Deist en Burden (1980:112) is van mening dat die gevaar bestaan dat wanneer tekste as 'vervuld' beskou word, so 'n teks sy eietydse relevansie verloor. Die gevaar bestaan ook dat die Nuwe Testament sy unieke 'belofte'-karakter verloor wanneer dit bloot as 'vervulling' van die Ou Testament beskou word (Bos 2008:ligging 736).

Dit kan egter gebeur dat daar slegs op die spesifieke en duidelike beloftes van die Ou Testament gekonsentreer word. Die Nuwe-Testamentiese siening van beloftevervulling, waarvolgens die hele $\mathrm{Ou}$ Testament hanteer word as belofte wat vervulling verwag (vgl. Greidanus 1999:206-207), word soms misgekyk. Die gevaar bestaan ook dat beloftes bloot as 'voorspellings' hanteer kan word (Bos 2008:ligging 731).

Von Rad (1980:155; vgl. Baars 2007:263) wys ook op 'n ander slaggat, naamlik dat die vervulling van beloftes in Christus as eenmalig en afgehandel beskou kan word. So 'n siening hou nie rekening met die verdere fokuspunt of

8.Greidanus (2007:10) gee die volgende voorbeeld hiervan aan die hand van Genesis 24: 'Abraham is a type of the Father who sent His servant (the Spirit) to obtain bride (Rebecca) for his son Isaac. The servant represents the Holy Spirit, and Isaac represents the Lord Jesus Christ ... Rebecca represents the Church.' vervullingsmoment van die beloftes nie, naamlik dat, by die wederkoms van Christus, elke belofte aangaande Hom sy finale en diepste vervulling sal bereik. Verder bestaan die gevaar ook dat die Ou Testament slegs as 'belofte' gesien word en nie as gesaghebbende, boodskapdraende openbaring van God nie (vgl. Buttrick 1987:356). So 'n siening kan daartoe aanleiding gee dat aartsvaderverhale van hulle inherente boodskap gestroop word.

Wanneer tipes verkeerd hanteer word en nie in Christus sy antitipe vind nie, het dit dikwels eksemplarisme ${ }^{9}$ en moralisme tot gevolg (vgl. Keller 2002:27; Fee \& Stuart 2003:103). Kaiser (1981:188) sluit hierby aan wanneer hy op die gevaar van 'reverse typology' wys. Hiervolgens word hedendaagse gebeure, optrede of omstandighede as reflekterend van die historiese gebeure gesien. Só 'n uitleg kan nie anders as om eksemplaries en moralisties te wees nie. Dit gebeur veral wanneer daar 'n oordrewe klem op die wil van die mens geplaas word (Keller 2002:18).

\section{Slot}

Die probleem rondom Christosentriese prediking is fundamenteel 'n hermeneutiese probleem. Daar bestaan 'n see van hermeneutiese moontlikhede waarvolgens die Ou-Testamentiese narratiewe vertolk kan word. Dit is dus nodig dat predikers wat Christus op 'n verantwoordelike wyse vanuit die $\mathrm{Ou}$ Testament wil verkondig, se hermeneutiese voete stewig geplant is voordat hulle hierdie taak aanpak. Die aanvaarding van die unieke karakter van die $\mathrm{Ou}$ Testament as uit die staanspoor Christelik, en die erkenning van die eenheid tussen die Ou en Nuwe Testament met slegs een boodskap, is onontbeerlike hermeneutiese ankers vir verantwoordelike Christosentriese prediking. Vervolgens behoort van 'n verantwoordelike eksegetiese metode gebruik gemaak te word. Die holistiese historieskritiese metode dien Christosentriese prediking die beste, aangesien dit die literêre, historiese en teologiese aspekte van 'n teks deeglik verreken. Ten einde sinvol (organies) vanuit die Ou-Testamentiese teks na Christus te beweeg, is dit nodig om die FCF van 'n teks te identifiseer. Daar is verskeie moontlikhede wat gekies kan word vir 'n oorgang na Christus. Hoewel hierdie metodes die moontlikheid van verantwoordelike Christosentriese prediking vanuit die Ou-Testamentiese narratiewe versterk, is hulle nie sonder leemtes nie. Om hierdie rede behoort predikers ook bewus te wees van die talle slaggate wat hierdie oorgange inhou.

Uiteindelik behoort die menslike eksegeet altyd te erken dat die Heilige Gees die eintlike Eksegeet is (vgl. De Klerk 2010:456). Hy behoort in biddende afhanklikheid die Woord te benader met die smeekgebed dat die Gees ook sy verstand sal open om die Skrif te verstaan (Luk 24:45) soos wat Hy eenmaal met sy dissipels gedoen het (Jonker 1976:34; Cilliers 2000:7-8).

9.Trimp (1988:74-106; vgl. ook Burge 2009) se bespreking van die 'exemplum' wys daarop dat daar binne die heilshistoriese benadering tog 'n plek vir die sinvolle hantering daarvan is. 


\section{Erkenning Mededingende belange}

Die outeurs verklaar dat hulle geen finansiële of persoonlike verbintenis het met enige party wat hulle nadelig kon beïnvloed in die skryf van hierdie artikel nie.

\section{Outeursbydrae}

Ds. H.S.W.S. (Noord-Wes Universiteit) het die grootste gedeelte tot hierdie artikel bygedra. Prof F.W.d.W. (NoordWes Universiteit) se bydra is gelewer in sy hoedanigheid as promotor en toesighouer.

\section{Literatuurverwysings}

Baars, A., 2007, 'Christusprediking vanuit het Oude Testament', Theologia Reformato 50(3), 242-266.

Beale, G.K. \& Carson, D.A. (eds.), 2007, Commentary on the New Testament use of the Old Testament, Baker Academy, Grand Rapids, MI.

Bos, R., 2008, We have heard that God is with you: Preaching the Old Testament, Kindle, Eerdmans, Grand Rapids, MI.

Bright, J., 1967, The authority of the Old Testament, Baker, Grand Rapids, MI.

Broadhurst, J., 2006, Preaching Christ from the Old Testament, viewed 26 June 2012, from http://www.preaching.com/resources/articles/11547805/

Burge, K., 2009, What's the Point? Moving from exegetical to homiletical, viewed 26 June 2012, from http://www.preaching.com/resources/articles/11622943/

Buttrick, D.G., 1987, Homiletic moves and structures, Fortress Press, Philadelphia.

Buttrick, D.G., 1988, Preaching Jesus Christ, Fortress Press, Philadelphia.

Chapell, B., 2001, What is expository preaching? Interview by M. Duduit, viewed 26 Junie 2012, from http://www.preaching.com/resources/articles/11565737/

Chapell, B., 2005, Christ-Centered Preaching: redeeming the expository sermon, 2nd ed, Baker, Grand Rapids, MI.

Childs, B.S., 1993, Biblical theology of the Old and New Testaments, Fortress Press, Minneapolis.

Ciampa, R.E. \& Rosner, B.S., 2007, '1 Corinthians', in G.K. Beale \& D.A. Carson (eds.) Commentary on the New Testament use of the Old Testament, pp. 695-752, Bake Academy, Grand Rapids, MI.

Cilliers, J.H., 2000, Die genade van gehoorsaamheid, Lux Verbi, Wellington.

Cilliers, J.H., 2008, 'Skrifbeskouing en Skrifhantering: perspektiewe op'n hermeneutiek van verwagting', Verbum et Ecclesia 29(1), 62-76. http://dx.doi.org/10.4102/ ve.v29i1.5

Clements, R.E., 1978, Old Testament theology: A fresh approach, Marshall, Morgan \& Scott, London.

Clowney, E.P., 1986, 'Preaching Christ from all the Scriptures', in S.T. Logan (ed.), The preacher and preaching: Reviving the art in the twentieth century, pp. 163-191, P\&R, Phillipsburg, NJ.

Clowney, E.P., 1988, The unfolding mystery: Discovering Christ in the Old Testament P\&R, Phillipsburg, NJ.

Clowney, E.P., 2003, Preaching Christ in all of Scripture, Crossway Books, Wheaton, IL.

Craddock, F.B., 1985, Preaching, Abingdon, Nashville, TN.

Davies, W.D. \& Allison, D.C., 1988, A critical and exegetical commentary on the gospe according to St. Matthew, T\&T Clark Limited, Edinburgh.

Davies, D.R., 2006, The Word became fresh, Christian Focus Publications Ltd, Fearn, Tain, Ross-shire.

Deist, F.E., 1978, Heuristics, hermeneutics and authority in the study of Scripture, University of Port Elizabeth, Port Elizabeth.

Deist, F.E. \& Burden J.J., 1980, Die ABC van Bybeluitleg, Van Schaik, Pretoria.

De Klerk, B.J., 2010, 'Die Heilige Gees en die prediking in die erediens', In die Skriflig $44(2), 455-473$

De Wet, FW., 2007, 'Jesus Christus, die Gekruisigde as oriëntasiepunt en hermeneutiese sleutel in die homiletiese proses', NGTT 48(3\&4), 457-470.

De Wet, F.W., 2011, Hoe lieflik is die Lig: 'n Verkenning van die dieptevlak van die homiletiese proses, Potchefstroomse Teologiese Publikasies, Potchefstroom.

Dijk, K., 1955, De dienst der prediking, Kok, Kampen.

Dingemans, G.D.J., 1991, Als hoorder onder de hoorders: Hermeneutische homiletiek, Kok, Kampen.

Fabiny, T., 2009, 'Typology: Pros and cons in Biblical hermeneutics and literary criticism (from Leonard Goppelt to Northrop Frye)', RILCE 25(1), 138-152.
Fee, G.D. \& Stuart, D., 2003, How to read the Bible for all its worth: A guide to understanding the Bible, 3rd ed., Zondervan, Grand Rapids, MI.

France, R.T., 1985, The gospel according to Matthew: An introduction and commentary, InterVarsity Press, Leicester.

Glenny, E., 1997, 'Typology: A summary of the present evangelical discussion', Journal of the Evangelical Theological Society 40(4), 627-638.

Goldsworthy, G., 2000, Preaching the whole Bible as Christian literature: The application of Biblical theology to expository preaching, Eerdmans, Grand Rapids, MI.

Goldsworthy, G., 2002, 'Biblical theology as the heartbeat of effective ministry', in S.J. Hafemann (ed.), Biblical theology, pp. 280-286, InterVarsity Press, Downers Grove, IL.

Goldsworthy, G., 2006, Gospel-centered hermeneutics: Biblical-theological foundations and principles, Apollos, Nottingham.

Greidanus, S., 1970, Sola Scriptura: Problems and principles in preaching historical texts, Wedge Publishing Foundation, Toronto.

Greidanus, S., 1988, The modern preacher and the ancient text: interpreting and preaching Biblical literature, Eerdmans, Grand Rapids, MI.

Greidanus, S., 1999, Preaching Christ from the Old Testament, Eerdmans, Grand Rapids, MI.

Greidanus, S., 2007, Preaching Christ from Genesis: Foundations for expository preaching, Eerdmans, Grand Rapids, MI.

Gundry, R.H., 1994, Matthew: A commentary on his handbook for a mixed Church under persecution, 2 nd ed., Eerdmans, Grand Rapids, MI.

Heyns, J.A., 1972, 'Die Skrif as daad van gehoorsaamheid', NGTT 13(1), 1-19.

Hoekstra, T., 1926, Gereformeerde Homiletiek, Zomer \& Keuning, Wageningen.

Janse van Rensburg, J., 2007, 'Prediking uit die Ou Testament', Acta Theologica 27(2), 105-127.

Jonker, W.D., 1976, Die Woord as opdrag, NG Kerkboekhandel, Pretoria.

Jordaan, G.J.C., Janse van Rensburg, F. \& Breed, D.G., 2011, 'Hermeneutiese vertrekpunte vir gereformeerde eksegese,' In die Skriflig 45(2\&3), 225-258.

Kaiser, W.C. jr., 1981, Toward an exegetical theology: Biblical exegesis for preaching and teaching, Baker Bookhouse, Grand Rapids, MI.

Kaiser, W.C. jr. \& Silva, M., 1994, An introduction to Biblical hermeneutics: The search for meaning, Zondervan, Grand Rapids, MI.

Kaiser, W.C. jr., 2008, Must every Christian lesson or sermon focus on Christ?, viewed 26 June 2012, from http://www.preaching.com/resources/articles/11584088/

Keller, T.J., 2002, Preaching the gospel in a post-modern world, Doctor of ministry program presented at Reformed Theological Seminary in January 2002, viewed 06 March 2010, from http://www.eucatastrophe.com/blog/wp-content/ uploads/2006/12/keller-on-preaching-syllabus.pdf

Keller, T.J., 2011, TGC Asks about cautions for Christ-Centered OT teaching, Interview by C. Hansen, viewed 31 July 2011, from http://thegospelcoalition.org/blogs/ tgc/2011/05/11/tgc-asks-about-cautions-for-christ-centered-ot-teaching/

Krabbendam, H., 1986, 'Hermeneutics and preaching', in S.T. Logan (ed.), The preacher and preaching: Reviving the art in the twentieth century, pp. 212-245, P \& R Phillipsburg, NJ.

Long, T.G., 1989, The witness of preaching, Westminster/John Kox, Louisville, KT.

Odendaal, J.W.S., 2006, 'Die Skrifbeskouing van die vroeë kerkvaders uit Afrika (veral Tertullianus en Augustinus) en hulle relevansie vir Suidelike Afrika', M.A.verhandeling, Fakulteit Teologie, Universiteit van Pretoria.

Peels, H.G.L., 2009, 'Hoe leest gij? Een lectio christiana van het Oude Testament', Theologia Reformata 52(3), 236-259.

Phillips, G.Y., Janse van Rensburg, F. \& Van Rooy, H.F., 2012, 'Developing an integrated approach to interpret New Testament use of the Old Testament', In die Skriflig 46(2), Art. \#50, 10 bladsye, viewed 28 November 2012, from http://www. indieskriflig.org.za/index.php/skriflig/article/viewFile/50/694

Ridderbos, H.N., 1950, De komst van het koninkrijk, Kok, Kampen.

Robbertze, H.C.G., n.d., Ou Testament 1: Hermeneutiek en metodiek van eksegese, Klasaantekeninge uitgereik in die Eenheid Ou Testament Eksegese, Afrikaanse Protestantse Akademie, Pretoria.

Robbertze, H.C.G., 2003, 'Prediking van die Ou Testament in die Christelike erediens', Tydskrif vir Christelike Wetenskap 39(3), 149-159.

Robinson, H.W., 1997, 'The heresy of application', Leadership Journal 18(4), 21-27, viewed 26 Junie 2012, from http://homepage.mac.com/bpirwin/knox/PDF\%20 Files/Application\%28Robinson\%29.pdf

Schilder, H.J., 1983, Het schrift dat niet verslijt: Opstellen over het Oude Testament, Uitgeverij Van Den Berg, Kampen.

Strauss, H.S.W., 2012, Christosentriese prediking in die AP Kerk - 'n praktiesteologiese studie, M.Th-verhandeling, Fakulteit Teologie, Noordwes Universiteit, Potchefstroom.

Strydom, M.C., 1989, Eksemplaries-heilshistories? Voortsetting van 'n onvoltooide gesprek, VCHO, Bloemfontein.

Tipton, L.G., 2011, 'The Gospel and redemptive historical hermeneutics', in J. Muether \& D. Olinger (eds.), Confident of beter things, pp. 185-214, Committee for the Historian of the Orthodox Presbyterian Church, Willow Grove, PA. 
Trimp, C., 1988, Heilsgeschiedenis en prediking: Hervatting van een onvoltooid gesprek, Van den Berg, Kampen.

Van der Walt, T., 1962, Die Koninkryk van God - naby!, Kok, Kampen.

VanGemeren, W.A., 1984, 'Israel as the Hermeneutical Crux in the Interpretation of Prophecy (II)', WTJ 46(2), 254-297.

VanGemeren, W.A., 1995, The progress of redemption: The story of salvation from creation to the New Jerusalem, Baker Books, Grand Rapids, MI.

Van Rooy, H.F., 2001, 'Christusprediking uit die Ou Testament. 'n Nuwe benadering tot 'n ou probleem', In die Skriflig 35(1), 81-99.

Verhoef, P.H., 1973, Metodiek van die eksegese, NG Kerk-Uitgewers, Elsiesrivier.
Verhoef, P.H., 1977, 'Die weg en brug tussen Ou-Testamentiese teks en prediking', NGTT 18(2), 145-157.

Von Rad, G., 1980, God at work in Israel, Abingdon, Nashville, TN.

Vos, C.J.A., 1995, Die blye tyding: Homiletiek uit 'n hermeneuties-kommunikatiewe perspektief, RGN, Pretoria.

Vos, G., 1980, 'Redemptive history and Biblical interpretation', in R.B. Gaffin (ed.), The shorter writings of Geerhardus Vos, Presbyterian and Reformed Publishing Co. Phillipsburg.

Webber, R.E., 2002, The younger evangelicals: Facing the challenges of the new world, Baker Books, Grand Rapids, MI. 